УДК 329.7-055.2(575.1)

РОЛЬ ЖЕНЩИНЫ В ОБЩЕСТВЕ: СОВРЕМЕННЫЙ ВЗГЛЯД НА ДЕЙСТВИТЕЛЬНОСТЬ

Гаффорова Мавлюда Курбонбоевна

Доктор философии (PhD) по сочиилогическим наукам Академия государственного управления при Президенте Республики Узбекистан,

Ташкент, Узбекистан

\title{
THE ROLE OF WOMEN IN SOCIETY: A MODERN VIEW OF REALITY
}

Gafforova M.K.

PhD of Social science

The Academy of Public Administration under the President of the Republic of Uzbekistan,

Tashkent, Uzbekistan

DOI: $10.31618 /$ ESU.2413-9335.2019.7.59.10-12

\begin{abstract}
АННОТАЦИЯ
В статье речь идет о приоритетных направлениях развития социальной сферы, повышению социально-политической активности женщин, усилению их роли в управлении государством и обществом, обеспечению занятости женщин, выпускниц профессиональных колледжей, широкому привлечению их к предпринимательской деятельности. Сегодняшний день возникло новое поколение, утвердил себя новый социальный институт «социальная активность», исторические эпохальные признаки утвердили женскую часть населения в её новом качестве: как наиболее активную и социально мобильную часть общества. В условиях рыночной экономики женщины приходят в бизнес, осваивают управление предприятием, вкладывают средства, руководят процессом. Характерность социальной активности женщины-узбечки в том, что она одновременно как мать, как хозяйка и как предприниматель в семье вносит вклад в развитие общества.
\end{abstract}

\section{ANNOTATION}

The article deals with priority directions for the development of the social sphere, the increase in the sociopolitical activity of women, the strengthening of their role in the governance of the state and society, the employment of women, the graduates of professional colleges, and the wide involvement of women in entrepreneurial activities. Today a new generation has emerged, the new social institution "social activism" has established itself, historical epochal signs have affirmed the female part of the population in its new quality: as the most active and socially mobile part of society. In a market economy, women come into business, master enterprise management, invest, manage the process. The character of the social activity of an Uzbek woman is that she simultaneously as a mother, as a mistress and as an entrepreneur in the family contributes to the development of society.

Ключевые слова. Предпринимательство, гончарное дело ремесле государство, политика, общество, женщина, социальная активность, развитие, поколение.

Keywords. Entrepreneurship, pottery craft state, politics, society, woman, social activity, development, generation.

За годы независимого развития Узбекистан добился больших успехов в защите прав и законных интересов женщин. Как отметил Президент Республики Узбекистан Ш.М.Мирзиёев: Когда счастлива женщина- счастливо все общество. Ведь она самое загадочное творение Всевышнего. Природа предоставила женщинам важнейшие функции, ведь главное назначение женщины на Земле-продолжать род человеческий. Благодаря женщинам жизнь приобретает еще более глубокий смысл, озаряется светом любви и доброты, в домах царят мир и благополучие. Испокон веков женщина является хранительницей очага, и по сей день остается источником самых благородных человеческих чувств и поступков. Но в разные периоды существования человечества роль женщины в обществе не была одинаковой. В любом современном обществе они занимают жизненно важную роль, позицию также принимают активное участие в общественно-политических и социально-экономических сферах. В настоящее время государственные реформы, переход на рыночную экономику направлены на развитие частного бизнеса и предпринимательства. Доказательством этому служат государственные законы и Указы Президента, принятые с целью развития и поддержки предпринимательства и частного бизнеса в Республике. Президент Узбекистана Ш.М.Мирзиёев Указом от 7 февраля 2017 года утвердил действий по пяти приоритетным направлениям развития страны в 2017-2021 годах. [1] Стратегия действий будет реализована в пять этапов, каждый из которых предусматривает утверждение отдельной ежегодной государственной программы по ее реализации в соответствии с объявляемым наименованием года (2019 год-Годом активных инвестиций и социального развития). B IVПриоритетных направлениях развития социальной сферы уделено большое внимание повышению социально-политической активности женщин, усилению их роли в управлении государством и обществом, обеспечению занятости женщин, выпускниц 
профессиональных колледжей, широкому привлечению их к предпринимательской деятельности. Наряду с мужчинами, женщины Узбекистана явно показали свою активность и способность в социально-экономической жизни. В условиях рыночной экономики женщины приходят в бизнес, осваивают управление предприятием, вкладывают средства, руководят процессом. Во всех временах узбекские женщины имели своё весомое место в обществе, активно участвовали в развитии духовной и социально-экономической жизни. Характерность социальной активности женщины- узбечки в том, что она одновременно как мать, как хозяйка и как предприниматель в семье вносит вклад в развитие общества. Узбекская мать, воспитывая дочь, готовя её к семейной жизни, обязательно учит своего ребенка какому-нибудь ремеслу. Сегодня в мире наблюдается прогресс в представленности женщин в политике, особенно на уровне национальных парламентов. И Узбекистан находится в русле международных тенденций. «Женщины играют жизненно важную роль в сохранении безопасности в стране. Особо актуальной задачей для нас является оградить и защитить наших детей от чуждых нам идей, любых угроз. В осуществлении этой очень важной задачи мы, в первую очередь, опираемся на активистов махалли [общин]», - отметил Президент Узбекистана Шавкат Мирзиёев в своем поздравлении 6 марта по случаю Международного женского дня. По словам Мирзиёева, женщины составляют более $87 \%$ консультантов по вопросам религиозного просвещения и духовно-нравственного воспитания в махаллях. Всего же в Узбекистане насчитывается около 9700 махаллей. Хочу особо отметить, что среди женщин нашей страны есть 514 докторов наук, 6 академиков, 15 Героев Узбекистана, 17 сенаторов, 15 депутатов Законодательной палаты, кроме того, женщины составляют более 23 процентов депутатов местных Кенгашей. Десятки наших женщин удостоены таких почетных званий, как “Заслуженный деятель науки Узбекистана”, “Народный поэт Узбекистана”, "Народный учитель Узбекистана", "Народный артист Узбекистана". 240 талантливых девушек являются лауреатами Государственной премии имени Зульфии, и в этом году их ряды будут пополнят еще 15 одаренных девушек. Сегодня мы с большим уважением называем имена сотен женщин, которые своим добросовестным трудом и весомыми достижениями в профессиональной сфере, активной деятельностью в государственных и общественных организациях, своими благородными качествами снискали уважение и авторитет среди нашего народа. В нашей стране 72 процента работающих в сферах науки, образования, здравоохранения, культуры и искусства-обратите внимание, 72 процента-составляют женщины [2]. Большая часть председателей и активистов органов самоуправления граждан-также женщины. Свыше 8,5 тысячи женщин эффективно работают в махаллях консультантами по вопросам религиозного просвещения и духовно-нравственного воспитания. Достижению нами высоких рубежей способствуют такие качества женщин нашей страны, как мудрость, терпение и выдержка, доброта и преданность, стремление к сохранению и укреплению атмосферы мира и стабильности, взаимного уважения и любви в семьях, нашем обществе в целом. Женщины вносят достойный вклад в развитие страны, составляя около 50 процентов всех занятых в различных отраслях экономики и социальной сферы. Среди них есть много известных людей - руководителей предприятий, организаций, ННО, фермеров, врачей, деятелей науки, культуры и образования.

Роль женщины в современном обществе велика. На сегодняшний день для поддержки и активизации способностей и возможностей женщин в сфере предпринимательства и бизнеса, для эффективного использования этих возможностей в социальной жизни в республике проделано ряд работ. Не зря в нашей республике задачи частной собственности, малого бизнеса и предпринимательства подняты на уровень государственной политики.

Из древне узбекский народ прославлен всему миру своими изделиями национального ремесла. Сегодня туристов, приезжающих из разных стран, иностранных инвесторов и бизнесменов всё больше привлекает этот сказочно красивый край. С одной стороны, они приезжают посмотреть на исторические памятники, с другой-поближе познакомиться с народным ремеслом, основанном на ручном труде. Вышитые руками узбекских женщин головные уборы, сотканные разнообразные шёлковые ткани поражают своим неповторимым колоритом. Современная женщина демонстрирует свои широкие способности и таланты в различных отраслях народного хозяйства. Если с одной стороны она без колебаний входит в сферу национального ремесла как гончарное дело, изобразительное искусство, скульптура, миниатюра и другие, то с другой стороны, широко и эффективно используя возможности, усердно развивает сельское хозяйство, производит товары народного потребления, улучшает сферу бытового обслуживания.

Создание со стороны государства грантовых средств, льготных кредитов, разработка различных проектов, направленных на развитие частного бизнеса и предпринимательства, принятые законодательных документов для поддержки экономической активности женщин большим изменениям в социальной жизни женщин Узбекистана. Из выше способствовали сказанного следует, что в современном мире уделяется большое внимание роли женщины в обществе. Так, в статье 63 Конституции Республики Узбекистан сказано «Семья основная ячейка общества и имеет право быть под защитой государства и общества». [3] В этом отношении в нашей стране составляются государственные программы, 2018 года «Годом поддержки активного предпринимательства, инновационных идей и технологий», создание и раскрытие перед женщинами широких возможностей в разных сферах общества ярко демонстрируют, что женщина в нашем обществе всегда уважаема и защищена. Примером этого является быстрый рост социально-экономической активности женщин в современном обществе. На сегодняшний день в каждой области республики 
ведутся проекты по вовлечению женщин в предпринимательство. В рамках этих инициатив сотрудники банков дают консультации женщинам, желающим открыть собственное дело, по вопросам составления бизнес-плана и получения кредитов. В этой работе упор делается на поддержку семейного предпринимательства, а также молодых безработных женщин, начинающих свой бизнес. В Узбекистане в 2017 году на развитие женского предпринимательства было направлено более триллион сумов. Эти средства не только на предоставление специальных льготных кредитов женщинам-предпринимателям, но и на реализацию мер по поддержке представительниц слабого пола в стремлении к бизнес [4] Ее основная цель расширение и защита экономических и социальных прав женщин, поддержка их предпринимательских и общественных инициатив, помощь в обеспечении финансовыми и информационными ресурсами.

Широкое участие женщин в избирательном процессе, станет индикатором их политической ак- тивности, своеобразной оценкой той широкомасштабной работы, которая проведена в стране по повышению роли женщины в обществе. Сегодня женщины работают и принимают важнейшие решения на самых ответственных участках, непосредственно связанных с обеспечением социального благополучия населения.

Список литературы

1.Указ Президента Республики Узбекистан Ш.М. Мирзиёева от 7 февраля 2017 года. Стратегия действий по пяти приоритетным направлениям развития Узбекистана в 2017-2021 годы.

2.Выступление Президента Ш.М. Мирзиёева на торжественной церемонии по случаю Международного женского дня 2017 год 6 марта.

3.Конституция Республики Узбекистан.

4.«Женщины в бизнесе и управлении» доклад Международной организации труда. 2017. http://www.mk.ru/social/2017/01/13/dokladmezhdunarodnoy-organizacii-truda-dolyazhenshhinrukovoditeley-v-mire-vsego-5.html

\title{
ПРОЕКТИРОВАНИЕ АГРО-ЭТНОКОМПЛЕКСОВ В РЕГИОНАХ РОССИЙСКОЙ ФЕДЕРАЦИИ С РЕКРЕАЦИОННОЙ СПЕЦИАЛИЗАЦИЕЙ
}

\author{
Геращенко Ирина Николаевна \\ Канд. геогр. наук, доиент кафедры арт-бизнеса, туризма и рекламы \\ Краснодарского Государственного Института Культуры, \\ Россия, г Краснодар \\ Сохина Наталья Петровна, \\ Студент \\ Краснодарского Государственного Института Культуры, \\ Россия, г. Краснодар \\ Баскакова Дарья Сергеевна \\ Магистрант \\ Краснодарского Государственного Института Культурь \\ Россия, г. Краснодар
}

\section{АННОТАЦИЯ}

В статье рассматриваются особенности проектирования предприятий интегрирующих в себе туристские услуги аграрного и этнического направления. Проанализировано современное состояние туристского рынка Туапсинского района Краснодарского края в области этно-агротуризма. Авторами спроектирован агро-этнокомплекса «Вишнёвый сад». В статье представлены основные положения проекта комплекса.

\section{ABSTRACT}

The article deals with the design features of enterprises integrating the tourist services of agricultural and ethnic areas. The current state of the tourist market of Tuapse district of Krasnodar region in the field of ethnoagrotourism is analyzed. The authors designed agro-ethnocomplex "Cherry orchard". The article presents the main provisions of the complex project.

Ключевые слова: проектирование, агро-этнокомплекс, продвижение, Туапсинский район, Краснодарский край.

Key words: design, agro-ethnocomplex, promotion, Tuapse district, Krasnodar region.

На данном этапе развития цивилизации, в связи с высоким уровнем загрязнения окружающей среды, неравномерным использованием природных ресурсов и очень быстрым темпом жизни, приобретает все большую популярность отдых на природе. Это тенденция характерна и для жителей городов России, что позволяет урбанизированным жителям отдохнуть от шума, познакомится с животным миром и позаботиться о природе, полностью погрузиться в историю и национальные особенности ведения быта определенной страны, познакомится с фольклорными особенностями и традициями страны. Именно такой вид отдыха могут предоставить предприятия аграрного и этнического направления. В связи этими факторами затронутая в данной научной работе тема является актуальной и требует детального изучения.

В последние годы во многих регионах России наблюдается развитие сельского туризма. В основном, аграрный туризм представлен в следующих видах: сдача комнат в сельской местности и в эко- 